\section{EREM $77 / 2$}

Journal of Environmental Research, Engineering and Management Vol. 77 / No. 2 / 2021 pp. 53-62 DOI 10.5755/j01.erem.77.2.23633
Changes in Salinity and Toxicity of Soil Contaminated with De-icing Agents during Growing Season

Received 2019/06

Accepted after revision 2021/03

\title{
Changes in Salinity and Toxicity of Soil Contaminated with De-icing Agents during Growing Season
}

\author{
Alexander Gerasimov*, Marina Chugunova \\ Scientific Research Center for Ecological Safety RAS, 18 Korpusnaya st., Saint Petersburg 197110 , \\ Russian Federation
}

\section{Yulia Polyak}

Scientific Research Center for Ecological Safety RAS, 18 Korpusnaya st., Saint Petersburg 197110 ,

Russian Federation

St. Petersburg State University, 7-9 Universitetskaya emb., Saint Petersburg, 199034, Russian Federation

\section{*Corresponding author: recchi@rambler.ru}

De-icing agents (ice and snow control materials) are applied to prevent ice and snow deposits on the roads in winter period. The extensive use of de-icing agents in countries with cold climate creates problems for the environment. In this study, the dynamics of de-icing salt concentrations in sod-podzolic soil was revealed in laboratory and field experiments. Twelve de-icing agents of different chemical groups (chlorides, acetates and formates) were studied. Under laboratory conditions, application of high doses of chloride reagents led to an increase of salt concentration in soil up to a level of slightly saline soils. Contaminated soils had salt levels high enough to be toxic to plants and soil microorganisms. However, under field conditions, soil salinity eventually decreased due to salt washout by atmospheric precipitation. By the end of the growing season, salt concentration corresponded to a background level. The decrease in salt concentration was accompanied by a decrease in soil toxicity. Acetate and formate de-icing agents demonstrated the least environmental effect. Our results suggest that magnesium chloride was the least harmful among the de-icers of chloride group while the most commonly used road de-icing salt sodium chloride was the most persistent and toxic to terrestrial plants and soil microbiota.

Keywords: de-icing salts, sod-podzolic soil, plants, microorganisms, environment. 


\section{Introduction}

The most sensitive components of urban environment are soils and plants. In megalopolises, a range of negative anthropogenic factors promotes the accumulation of pollutants in the soil. De-icing agents are among the most environmentally hazardous (Yakubov and Nikolayevskiy, 2001; Coldsnow et al., 2017; Nutile and Solan, 2019). De-icing agents are chemical reagents applied to prevent ice and snow deposits on the roads and increase human safety for those traveling during dangerous winter conditions.

Many scientists have been engaged in the research of de-icing agents for decades, and they have covered various aspects of this problem. The impact and distribution of de-icing salt in soils have been studied in the North America (Cain, 2001; Jacobi et al., 2009), European and Asian countries (Yakubov and Nikolayevskiy, 2001; Soundararajan et al., 2019; Ke et al., 2019). Different properties of soils contaminated with de-icing agents are investigated (TRB, 2008; Vasil'yev, 2008).

Most de-ices are based on inorganic chloride salts, i.e. sodium chloride $(\mathrm{NaCl})$, magnesium chloride $\left(\mathrm{MgCl}_{2}\right)$, and calcium chloride $\left(\mathrm{CaCl}_{2}\right)$ (Asensio et al., 2017). Among de-icers based on salts of other chemical groups are acetates (potassium and ammonium acetates), nitrates (calcium, magnesium and carbamide nitrates), formates (potassium and sodium formates), and ammonium salts (urea and carbamide-ammonium nitrates). Friction materials such as sand, crushed stone, marble and granite chips are actively used as de-icers as well. Some de-icing agents have a complex chemical composition and consist of several components. Most previous studies of the effects of de-icing salts have focused on the environmental impact of technical salt, while de-icing agents of new generation have not been given enough attention in scientific publications (Cunningham et al., 2008; Nutile and Solan, 2019).

Traditionally, significant amounts of de-icing agents are used in northern countries (Green et al., 2019). Reagents of the chloride group are the dominant de-icers in many cities including St. Petersburg, Russia. Their usage on the roads significantly exceeds the use of acetate, nitrate and formate de-icers. After application, de-icing salts dissolve and enter soil and freshwater ecosystems. Penetrating in large quantities into roadside soils, de-icers can result in a negative effect on soil, ground and surface waters, and plant vegetation. Soil salinization from de-icers heads the list of hazardous agents affecting plant vegetation in urban environment (NCHRP, 2007).

The impact of de-icers on soil ecosystems depends on many factors. These include the distance from the roadway, the season, the landscape, the duration of impact, the soil texture, the presence (or absence) of drainage, rainfall, air temperature, wind, humidity and other factors (Cain et al., 2001). De-icing agents accumulate in soil, and change soil chemical composition and physical characteristics. Over time, they can cause structural and functional changes in a soil ecosystem, which lead to the future stress and death of plants and soil microorganisms (Azovtseva, 2004).

The mechanism of such an effect is based on high concentration of salts in the soil solution that interferes with balanced absorption of essential nutritional ions by plants (Muchate et al., 2016). High salinity has a negative effect on major plant processes such as disrupting the osmotic and ionic equilibrium, protein synthesis, photosynthesis, energy, and lipid metabolism (Tester and Devenport, 2003). In this situation, the absorption of water by plants is disturbed, and the phenomenon of physiological drought occurs.

Plant viability decreases as salts accumulate in the soil, and they become more sensitive to plant pathogens and anthropogenic factors (Yakubov and Nikolayevskiy, 2001). Plant death is observed after de-icer application in landscaped areas in spring if there was little rain or no precipitation. In this case, the salts stay in the surface layer of the soil for a long time after snow melt, increasing the osmotic pressure of the soil solution. The salt accumulation does not occur during heavy spring rains, because the soil profile is washed by rainfall.

In addition to affected plants de-icing salts can affect soil microbial communities by causing changes in the composition and activity of microorganisms (Vasil'yev, 2008). The structure and species diversity of soil microbiota change due to the negative effect of de-icing agents on the chemical, physical and physical-chemical properties 
of the soil. Thus, de-icing agents are able to change the geochemical conditions of vegetation in landscaped areas and the functioning of soil microorganisms that threatens them with future stress and death. The aim of our study was to explore changes of salt concentrations in soil over time (during one growing season), and to evaluate the most environmentally friendly de-icers along with determination of their acceptable doses.

\section{Materials and Methods}

Twelve de-icing agents of different chemical compositions used to maintain clear roads in the last decade were selected for the present study. Reagents of the acetate and formate groups, which have recently become more common, were studied along with the most widely used chloride salts. The chloride group was represented by sodium chloride (technical salt), magnesium chloride ("Bishofit" reagent), calcium chloride ("TOR", "Unipell"), and mixtures of various chlorides: "Icemelt" (mixture of $\mathrm{CaCl}_{2}$ and $\mathrm{NaCl}$ ), "Ejik" (mixture of $\mathrm{CaCl}_{2}$ and $\mathrm{NaCl}$ ), "No Ice" (mixture of $\mathrm{NaCl}, \mathrm{KCl}$ and $\mathrm{Na}_{2} \mathrm{SO}_{4}$ ), "Rockmelt" (mixture of $\mathrm{MgCl}_{2}$ and different additives), and "Rockmelt-Eco" (mixture of $\mathrm{NaCl}, \mathrm{CaCl}_{2}$, marble crips and different additives). The acetate group was represented by reagent "Nordway" (potassium acetate). The formate group included two types of reagent "Clearway F-1" (sodium formate) produced in Russia and Finland. In accordance with the specifications, the following de-icer dosages were chosen: $20 \mathrm{~g} / \mathrm{m}^{2}, 50 \mathrm{~g} / \mathrm{m}^{2}$ and $150 \mathrm{~g} / \mathrm{m}^{2}$. On average, $20 \mathrm{~g} / \mathrm{m}^{2}$ is the minimum dose of de-icers for road treatment, while $150 \mathrm{~g} / \mathrm{m}^{2}$ is the maximum dose. Reagents were applied to the soil in dissolved form.

Experiments with de-icers were conducted in laboratory and field conditions. The cultivated sod-podzolic loamy soil was used for laboratory experiments. The soil was moistened to $60 \%$ of maximum water holding capacity; thereafter, it was composted for 10 days at a room temperature. At the end of the composting, the soil was placed in 1-liter plastic containers and lawn grass was sown in each container. We used grass mixture "Universal" of the following composition: perennial ryegrass (Lolium perenne), Kentucky bluegrass (Poa pratensis), creeping bentgrass (Agrostis stolonifera), meadow fescue (Festuca pratensis) and orchard grass
(Dactylis glomerata). A month later, grass biomass was determined, and soil samples were taken for analyses. All treatments were replicated four times. Soil without the addition of de-icers served as control.

Field experiments were carried out at the trial field near St. Petersburg, Russia ( $\left.59^{\circ} 44^{\prime} 34^{\prime \prime} \mathrm{N}, 30^{\circ} 22^{\prime} 49^{\prime \prime} \mathrm{E}\right)$. The soil investigated was a loamy podzol with $\mathrm{pH}_{\mathrm{H} 2 \mathrm{O}}$ of 6.8. Experimental plots were established separately in the flattened part of the study area. The size of the plots was $50 \times 25 \mathrm{~cm}$. There were four replications from each plot. The soil was treated with $20 \mathrm{~g} / \mathrm{m}^{2}, 50 \mathrm{~g} / \mathrm{m}^{2}$ and $150 \mathrm{~g} / \mathrm{m}^{2}$ of de-icing agents at the beginning of the growing season (in May). Lawn grass mixture "Universal" was sown on plots after treatment. At the end of the growing season (the end of September), soil samples were taken from these plots for laboratory analyses. Sampling was carried out from a depth of $0-20 \mathrm{~cm}$ from 3 points of each plot, after which a combined sample was formed by mixing.

The soil samples were air-dried at a room temperature, and sieved in $2 \mathrm{~mm}$ sieves. The measurement of soil salinity was performed using electrical conductivity of aqueous extracts from soil samples. The electrical conductivity was measured from extracts with soil to water ratios in weights of 1:5. For the preparation of water extracts from soil, the standard method was applied (GOST, 2011). Salt concentration of the extract was determined using the multiband conductometer HI 8733 (HANNA Instruments, Germany). All the electrical conductivities were expressed in $\mathrm{dS} / \mathrm{cm}$ at $25^{\circ} \mathrm{C}$.

To determine the impact of de-icers on higher plants, we used toxicity bioassay and measured the grass aboveground biomass. Toxicity bioassay was based on the germination and growth of the common wheat Triticum aestivum $\mathrm{L}$. (FR, 2006). The soil sample was put into 100 $\mathrm{mm}$ diameter Petri dishes with the moisture adjusted to $60 \%$ of maximum water holding capacity. 20 seeds with $>90 \%$ germination ability were arranged on the soil surface. The test dishes were incubated at $20^{\circ} \mathrm{C}$ for $72 \mathrm{~h}$. The measurement endpoints used were seed germination and seedling growth (roots and shoots). To measure grass aboveground biomass, we weighted plants from each plot. Plants were cut at their base.

We measured soil respiration using alkali absorption method (Alef, 1995). The soil sample was spread on the bottom of a $500-\mathrm{mL}$ glass jar and reaction container with 
$20 \mathrm{~mL} \mathrm{NaOH}(0.02 \mathrm{~N})$ solution was suspended inside the jar, above the soil. After incubation at $25^{\circ} \mathrm{C}$ for $24 \mathrm{~h}, 2$ drops of phenolphthalein indicator were added into the reaction containers, and then titrated with $0.02 \mathrm{~N} \mathrm{H}_{2} \mathrm{SO}_{4}$. The jars without soil served as controls. The difference in the consumed volume of $\mathrm{H}_{2} \mathrm{SO}_{4}$ between the treatment and the control was used to calculate the quantity of $\mathrm{CO}_{2}$ emission from soil microorganisms. The quantity of $\mathrm{CO}_{2}$ (the ratio of respiration) was calculated as $\mu \mathrm{g} \mathrm{CO} / \mathrm{C} \mathrm{g} \mathrm{h}$. All results were analyzed by one-way ANOVA using SPSS 25.0 statistical software. The significant differences between the means of parameters $(n=4)$ were determined by using the Duncan test $(p<0.05)$. The treatments with de-icers were compared with control unpolluted soil, and significant differences were given with different letters.

\section{Results and Discussion}

To assess the fate of de-icing agents in soil after treatment, we determined the concentration of water soluble salts by measuring the electrical conductivity of water extracts from soil. The determination of concentration of water soluble salts in soil solution by electrical conductivity is one of the generally accepted and widely used methods in soil science (Vozbutskaya, 1968). This method is used, in particular, to assess soil salinity (Vorob'yeva et al., 2012). Electrical conductivity is one of the most convenient and reliable parameters, which makes it possible to accurately estimate the degree of mineralization of soil solutions (Kopikova, 1985) and soil salinity (Tolpeshta et al., 2000; Sotneva, 2005). Pankova et al. (2006) developed a special scale for assessing the degree of soil salinity depending on electrical conductivity. Thus, the magnitude of the electrical conductivity may reliably and objectively characterize the degree of soil salinity under the conditions of our model experiments.

The results of the laboratory study of the effect of soil contamination with de-icing agents on soil salinity are presented in Table 1.

Soil contamination with the maximum dose of chloride de-icers $\left(150 \mathrm{~g} / \mathrm{m}^{2}\right)$ led to an increase of salt concentration in the soil (up to 18-36 times). The treatment of soil with some chloride salts increased soil salinity to the level of slightly saline soils $(4 \mathrm{mS} / \mathrm{cm})$. Moreover, the threshold value of soil salinity was decreased recently to $2 \mathrm{mS} / \mathrm{cm}$

Table 1. The effect of soil contamination with de-icing agents on the electrical conductivity of water extracts from soil (mS/cm) - a laboratory study

\begin{tabular}{|c|c|c|c|c|c|}
\hline & \multirow{2}{*}{$\begin{array}{l}\text { De-icing agents } \\
\text { Control }\end{array}$} & \multicolumn{4}{|c|}{ Dose of de-icing agents, $\mathrm{g} / \mathrm{m}^{2}$} \\
\hline & & \multirow{2}{*}{$\begin{array}{c}20 \\
0.11^{a}\end{array}$} & \multirow{2}{*}{$\begin{array}{c}50 \\
0.72^{b}\end{array}$} & \multirow{2}{*}{$\begin{array}{c}150 \\
1.56^{c}\end{array}$} & \multirow[b]{2}{*}{3.92} \\
\hline \multirow{9}{*}{ Chloride group } & Technical salt ( $\mathrm{NaCl})$ & & & & \\
\hline & Bishophit $\left(\mathrm{MgCl}_{2}\right)$ & $0.11^{\mathrm{a}}$ & $0.28^{b}$ & $0.67^{c}$ & $2.00^{d}$ \\
\hline & $\operatorname{TOR}\left(\mathrm{CaCl}_{2}\right)$ & $0.11^{a}$ & $0.44^{\mathrm{b}}$ & $0.99 c$ & $2.77^{d}$ \\
\hline & Unipell $\left(\mathrm{CaCl}_{2}\right)$ & $0.11^{a}$ & $0.38^{b}$ & $0.77^{c}$ & $2.20^{d}$ \\
\hline & Rockmelt ( $\mathrm{MgCl}_{2}+$ additives) & $0.11^{\mathrm{a}}$ & $0.38^{b}$ & $0.74^{c}$ & $2.05^{d}$ \\
\hline & Rockmelt-Eco ( $\mathrm{NaCl}+\mathrm{CaCl}_{2}+$ additives $)$ & $0.11^{\mathrm{a}}$ & $0.34^{b}$ & $0.71^{c}$ & $2.25^{d}$ \\
\hline & Icemelt $\left(\mathrm{CaCl}_{2}+\mathrm{NaCl}\right)$ & $0.11^{a}$ & $0.46^{b}$ & $1.20^{c}$ & $3.45^{d}$ \\
\hline & Ejik $\left(\mathrm{CaCl}_{2}+\mathrm{NaCl}\right)$ & $0.11^{\mathrm{a}}$ & $0.52^{b}$ & $1.14^{c}$ & $2.89^{d}$ \\
\hline & No ice $\left(\mathrm{NaCl}+\mathrm{KCl}+\mathrm{Na}_{2} \mathrm{SO}_{4}\right)$ & $0.11^{a}$ & $0.60^{b}$ & $1.04^{c}$ & $3.96^{d}$ \\
\hline \multirow{2}{*}{ Formate group } & Clearway $\mathrm{F}-1_{\text {rus. }}(\mathrm{HCOONa})$ & $0.11^{\mathrm{a}}$ & $0.13^{b}$ & $0.16^{b}$ & $0.27^{c}$ \\
\hline & Clearway F-1 $1_{\text {fin. }}(\mathrm{HCOONa})$ & $0.11^{\mathrm{a}}$ & $0.12^{a}$ & $0.14^{a}$ & $0.23^{b}$ \\
\hline Acetate group & Nordway $\left(\mathrm{CH}_{3} \mathrm{COOK}\right)$ & $0.11^{\mathrm{a}}$ & $0.10^{b}$ & $0.09^{c}$ & $0.16^{d}$ \\
\hline
\end{tabular}


Table 2. The effect of soil contamination with de-icing agents on the electrical conductivity of water extracts from soil $(\mathrm{mS} / \mathrm{cm})$ - a field study

\begin{tabular}{|c|c|c|c|c|c|}
\hline & \multirow{2}{*}{$\begin{array}{l}\text { De-icing agents } \\
\text { Control }\end{array}$} & \multicolumn{4}{|c|}{ Dose of de-icing agent, $\mathrm{g} / \mathrm{m}^{2}$} \\
\hline & & 20 & 50 & 150 & \\
\hline \multirow{6}{*}{ Chloride group } & Technical salt ( $\mathrm{NaCl})$ & $0.09^{a}$ & $0.14^{b}$ & $0.17^{c}$ & $0.29^{d}$ \\
\hline & Bishophit $\left(\mathrm{MgCl}_{2}\right)$ & $0.09^{a}$ & $0.14^{a}$ & $0.13^{\mathrm{a}}$ & $0.14^{a}$ \\
\hline & Rockmelt-Eco ( $\mathrm{NaCl}+\mathrm{CaCl}_{2}+$ additives $)$ & $0.09^{a}$ & $0.12^{b}$ & $0.13^{b}$ & $0.19^{c}$ \\
\hline & Icemelt $\left(\mathrm{CaCl}_{2}+\mathrm{NaCl}\right)$ & $0.09^{a}$ & $0.17^{\mathrm{b}}$ & $0.16^{\mathrm{b}}$ & $0.17^{b}$ \\
\hline & $\mathrm{Ejik}\left(\mathrm{CaCl}_{2}+\mathrm{NaCl}\right)$ & $0.09^{a}$ & $0.17^{\mathrm{b}}$ & $0.17^{\mathrm{b}}$ & $0.19^{c}$ \\
\hline & No ice $\left(\mathrm{NaCl}+\mathrm{KCl}+\mathrm{Na}_{2} \mathrm{SO}_{4}\right)$ & $0.09^{a}$ & $0.12^{\mathrm{b}}$ & $0.14^{\mathrm{c}}$ & $0.24^{d}$ \\
\hline Formate group & Clearway F-1 $1_{\text {fin. }}(\mathrm{HCOONa})$ & $0.09^{a}$ & $0.07^{\mathrm{a}}$ & $0.08^{\mathrm{a}}$ & $0.11^{\mathrm{b}}$ \\
\hline Acetate group & Nordway $\left(\mathrm{CH}_{3} \mathrm{COOK}\right)$ & $0.09^{a}$ & $0.09^{a}$ & $0.12^{b}$ & $0.18^{c}$ \\
\hline
\end{tabular}

(Pankova et al., 2006). A similar threshold value of soil salinity was found for crop yield of Lolium perenne and Festuca pratensis used in street lawn plantings (Bagdasaryan, 2008). Among all chloride de-icing agents, magnesium chloride de-icer caused less soil salinity, which is in line with other studies (Jacobi et al., 2009).

In soils contaminated with average doses of chloride de-icers $\left(50 \mathrm{~g} / \mathrm{m}^{2}\right)$, the maximum electrical conductivity reached $1.56 \mathrm{mS} / \mathrm{cm}$, which can be considered as a permissible level. At the same time, salinity of the soil treated with acetate and formate de-icers did not exceed the control value regardless of the reagent concentration.

The laboratory studies are known to provide a high level of control over the experiment. Soil mesocosm is isolated from external effects, and the experiment is performed in a controlled environment (the same temperature, humidity, etc.). Thus, the impact of the outside factors is minimized, and laboratory experiments provide a high confidence level. Nevertheless, there are important limitations, associated with laboratory studies. The properties of the soil change dramatically during long-term incubation in the laboratory, thus complicating interpretation of any observed effects (Polyak et al., 2018). Additionally, most of the laboratory studies are focused on the short-term effects, seen after a few weeks or even days of contamination, while the study of a longer period is uncommon.

To reproduce the changes which take place under natural conditions with time, we studied the effect of soil contamination with de-icing agents on soil salinity in field experiments at the trial field near St. Petersburg. The electrical conductivity of water extracts from soil measured at the end growing season is represented in Table 2 .

Salt concentration in the soil decreased to the background level at the end of the growing season in the field. Under the influence of external factors, the highest value of electrical conductivity did not exceed $0.29 \mathrm{mS} / \mathrm{cm}$ even in the soil contaminated with the maximum dose of technical salt $(\mathrm{NaCl})$. This may be due to the almost complete leaching of the de-icing agents during the growing season from the upper soil horizons. Earlier, Asensio et al. (2017) demonstrated that the de-icing salt moved to other areas by runoff water, and leaching of salt cations occurred faster in sodic soils.

To assess the salt reduction rate, we determined the salinity of the soil contaminated with two chloride de-icers ("No ice" and "Rockmelt-Eco") two weeks, one and a half, and four months after contamination in a field experiment. Soil salinity changed dramatically during the experiment (Table 3).

A decrease in salinity was noted in the shortest time (2 weeks after contamination). After a month and a half, the salt content reduced almost to the control value (the highest value was $0.32 \mathrm{mS} / \mathrm{cm}$ ). Later on, a further decrease in salt concentration was observed. At the end of the growing season, the electrical conductivity in water extracts from contaminated soils did not exceed $0.24 \mathrm{mS} / \mathrm{cm}$. 
Table 3. The dynamics of electrical conductivity in water extracts from contaminated soils during the growing season (mS/cm) - a field study

\begin{tabular}{|c|c|c|c|c|c|}
\hline \multirow{2}{*}{ De-icing agents } & \multirow{2}{*}{ Concentration, $\mathrm{g} / \mathrm{m}^{2}$} & \multicolumn{4}{|c|}{ Time after contamination } \\
\hline & & Initial & 2 weeks & 1.5 months & 4 months \\
\hline Control & 0 & $0.11^{a}$ & $0.11^{\mathrm{a}}$ & $0.16^{a}$ & $0.09^{a}$ \\
\hline \multirow{3}{*}{$\begin{array}{c}\text { No ice } \\
\left(\mathrm{NaCl}+\mathrm{KCl}+\mathrm{Na}_{2} \mathrm{SO}_{4}\right)\end{array}$} & 20 & $0.60^{b}$ & $0.34^{b}$ & $0.19^{a}$ & $0.12^{b}$ \\
\hline & 50 & $1.04^{c}$ & $0.65^{c}$ & $0.25^{b}$ & $0.14^{c}$ \\
\hline & 150 & $3.96^{d}$ & $1.80^{\mathrm{d}}$ & $0.32^{c}$ & $0.24^{d}$ \\
\hline \multirow{3}{*}{$\begin{array}{l}\text { Rockmelt-Eco } \\
\left(\mathrm{NaCl}+\mathrm{CaCl}_{2}+\right. \\
\text { additives })\end{array}$} & 20 & $0.34^{b}$ & $0.33^{b}$ & $0.19^{a}$ & $0.12^{b}$ \\
\hline & 50 & $0.71^{c}$ & $0.53^{c}$ & $0.17^{a}$ & $0.13^{b}$ \\
\hline & 150 & $2.25^{d}$ & $1.01^{d}$ & $0.29^{b}$ & $0.19 c$ \\
\hline
\end{tabular}

Toxicity bioassays using seeds of wheat Triticum aestivum L., grass aboveground biomass and soil microbial activity determination were performed in autumn to evaluate the toxic effect of de-icing agents on plants and soil microorganisms. The impact of de-icers on wheat seeds, plant biomass and soil respiration were studied in laboratory and field conditions. Laboratory experiments demonstrated high toxicity of de-icers to plants and microorganisms, while in field studies the decrease in the amount of de-icing salts was accompanied by the decrease in toxicity of contaminated soil by the end of the growing season (Fig. 1-3).

Fig. 1. Impact of de-icing agents on phytotoxicity of contaminated soil (A - laboratory experiment, B - field study)
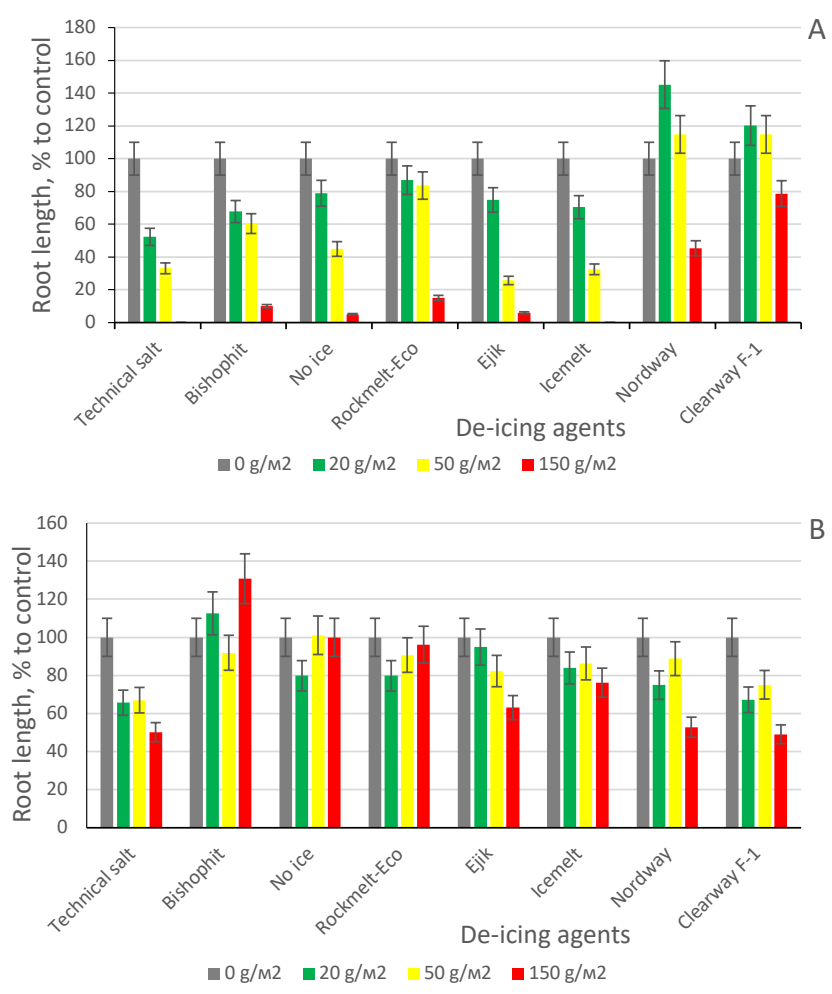
Fig. 2. Impact of de-icing agents on plant biomass ( $A$ - laboratory experiment, B - field study)

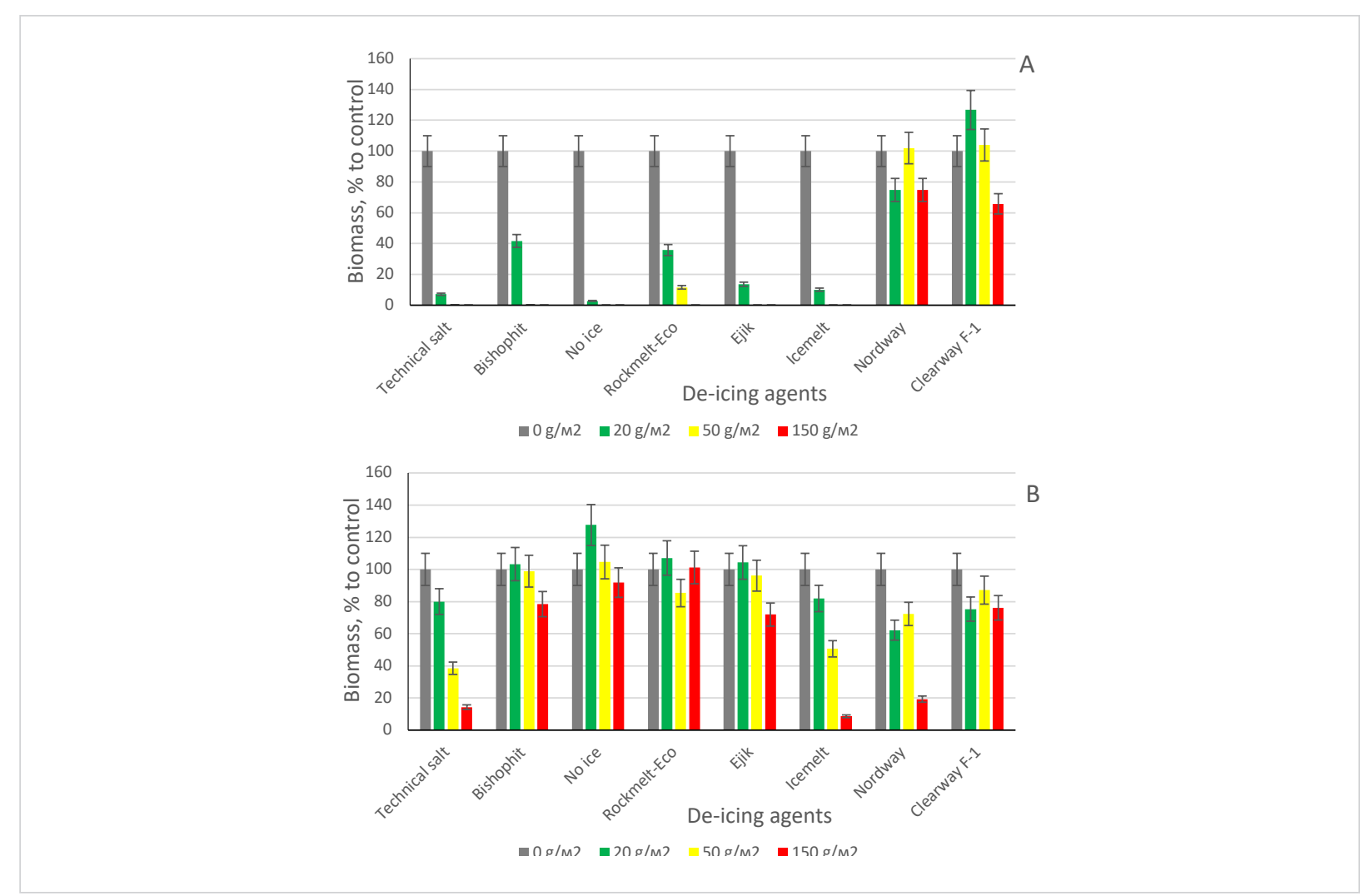

The most pronounced decrease in toxicity to higher plants at the end of the growing season was observed for the chloride group of de-icers: technical salt $(\mathrm{NaCl})$, "Bishophit" $\left(\mathrm{MgCl}_{2}\right)$, "No ice" $\left(\mathrm{NaCl}+\mathrm{KCl}+\mathrm{Na}_{2} \mathrm{SO}_{4}\right)$, "Rockmelt-Eco" ( $\mathrm{NaCl}+\mathrm{CaCl}_{2}+$ additives), "Icemelt" $\left(\mathrm{CaCl}_{2}+\right.$ $\mathrm{NaCl}$ ), and "Ejik" ( $\left.\mathrm{CaCl}_{2}+\mathrm{NaCl}\right)$ (Fig. 1b). In the soil with maximum doses of de-icing agents, an inhibition of root length of wheat decreased from $85 \%-100 \%$ to $50 \%$ (technical salt), or to zero ("No ice"). The other chloride reagent "Bishofit" $\left(\mathrm{MgCl}_{2}\right)$ even had a stimulating effect on wheat seeds. In autumn, the root length exceeded the value of the root length for the control soil by 30.8\% (Fig. 1b).

Toxic effect reduction was found for plant biomass in the field study. In the soil contaminated with chloride deicers, $86 \%-100 \%$ inhibition of plant growth was observed in laboratory experiments (Fig. 2a). In field experiments, the toxicity of the soil decreased from a practically lethal effect to a nearly non-toxic soil at the end of the growing season (Fig. 2b). The two exceptions were technical salt $(\mathrm{NaCl})$ and "Icemelt" $\left(\mathrm{CaCl}_{2}+\mathrm{NaCl}\right)$. The soil contaminated with the maximum dose of these reagents $\left(150 \mathrm{~g} / \mathrm{m}^{2}\right)$ remained toxic for plants, although at lower concentrations $\left(20 \mathrm{~g} / \mathrm{m}^{2}\right.$ and $\left.50 \mathrm{~g} / \mathrm{m}^{2}\right)$ the effect no longer exceeded the degree of moderate toxicity.

The impact of de-icers on soil microbiota was determined by the carbon dioxide release (soil respiration), which characterizes the microbial activity and integral intensity of the biodegradation processes of organic matter occurring in soils. Most of de-icers were not toxic to soil microbiota in laboratory conditions (Fig. 3). Only technical salt $(\mathrm{NaCl})$ and "Icemelt" $\left(\mathrm{CaCl}_{2}+\mathrm{NaCl}\right)$ had a strong inhibitory effect, but in the field conditions all de-icers were not toxic to soil microorganisms.

Acetate ("Nordway") and formate ("Clearway F-1") reagents had a strong stimulating effect on the activity of microorganisms in laboratory experiments. In the soil contaminated with these reagents, microbial activity exceeded the control level by $57 \%-74 \%$. However, this cannot be called a positive phenomenon, since such hypertrophied microbial activity can also bring the soil 
ecosystem out of the normal functioning further leading to its destruction (Zvyagintsev, 1987; Zvyagintsev et al., 2005). By the end of the growing season, the stimulating effect of acetate and formate reagents passed, and they had no significant effect on the intensity of soil respiration. Similar patterns of the dynamics of biological indicators of soils contaminated with de-icers during the growing season have been found in previous studies (Gerasimov, Chugunova, 2016; Gerasimov, Chugunova, 2018).

A decrease in soil salinity can be explained mainly by the leaching of salts from the upper soil horizons by precipitation. The area has a humid continental climate with the average annual temperature, precipitation and air humidity of $5.8^{\circ} \mathrm{C}, 660 \mathrm{~mm}$ and $78 \%$, respectively. The soil moisture in the area of St. Petersburg is mostly high, since evapotranspiration is low due to the cool climate. This climatic condition and soil washout by atmospheric precipitation, in general, allow the use of all studied de-icing agents including de-icers based on chlorides. Soils have time to clean, and the accumulation of salts in the soil does not occur.
Nevertheless, it is necessary to take into account the variability of external factors, for example, a dry summer, when the processes of soil desalinization can slow down dramatically. Moreover, leaching may ameliorate toxicity for land plants but accelerate inputs to aquatic ecosystems (Cunningham et al., 2008). It is also important to note that the maximum harmful effect of reagents on plants and soil microorganisms occurs in the second half of spring, immediately after the end of the winter season. At this time, soil salinity is at its highest level, while plants are just entering a period of active growth, and they are the least pollutant resistant. Accordingly, the harmful effect of de-icers on plants is greatest in April and May.

Currently, the widespread use of acetate and formate reagents that are harmless to plants is limited by their high cost. Therefore, the application of the cheaper chloride de-icing agents is more common, and this situation will not change in the near future. Taking into account these objective factors, de-icing agents based on magnesium chloride can be defined as the least environmentally hazardous. Salt concentration in the soil contaminated with magnesium chloride is several times lower than that of other chloride de-icers.

Fig. 3. Effect of de-icing agents on soil respiration rate ( - laboratory experiment, $B$ - field study)

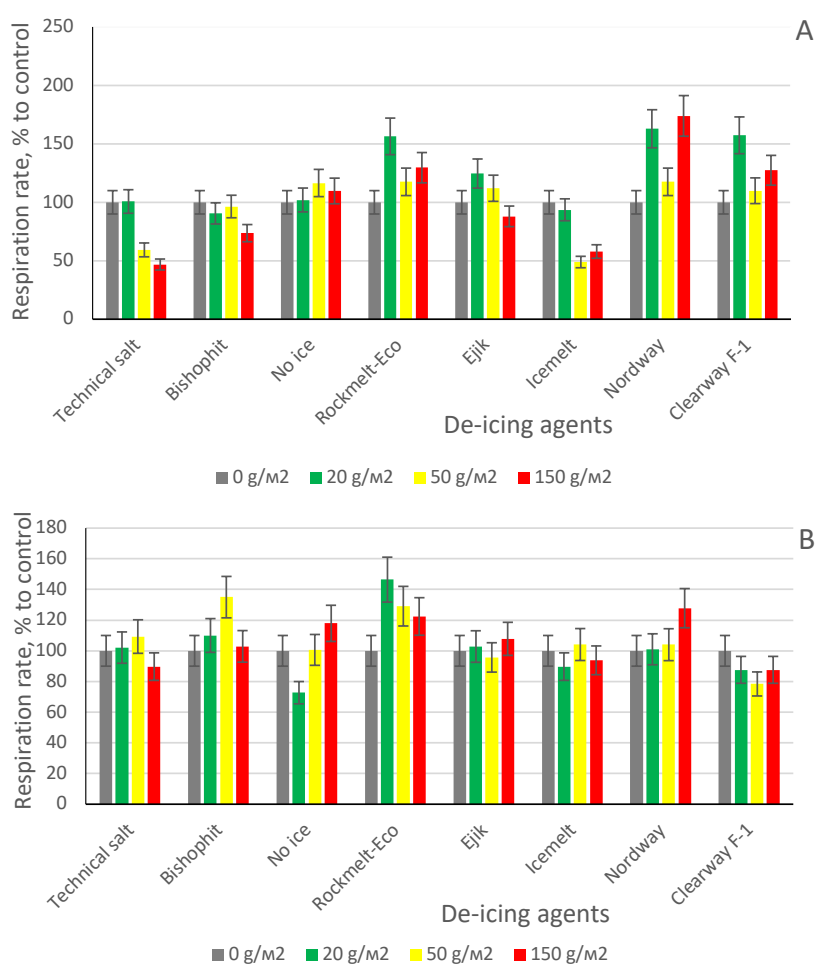




\section{Conclusions}

Many ecosystems worldwide are threatened by high salinity caused by human activities. The extensive use of de-icing agents leads to soil salinization that affects plant vegetation and creates problems for the environment. The results of our study show that acetate and formate de-icers do not change soil salinity, and generally have no effect on plant growth and soil microbial activity. Chloride de-icers in a dose of $150 \mathrm{~g} /$ $\mathrm{m}^{2}$ increased salt concentration in the soil to the level corresponding to low salinity, which is potentially dangerous for plants and soil microorganisms. Therefore, the use of chloride reagents in these doses should be limited. Among chloride de-icers, preparations based on magnesium chloride are the least environmentally hazardous while sodium chloride based preparations are the most toxic. However, the degree of soil salinity, caused by de-icing agents, is reduced during the growing season due to their washout in the upper

\section{References}

Alef K. (1995) Soil respiration in: Methods in applied soil microbiology and biochemistry. In: Alef K., Nannipieri P. (ed), Academic Press, Harcourt Brace \& Company, London, pp. 214-219.

Asensio E., Ferreira V.J., Gil G., García-Armingol T., López-Sabirón A.M., Ferreira G. (2017) Accumulation of De-lcing Salt and Leaching in Spanish Soils Surrounding Roadways. Int. J. Environ. Res. Public Health 14(12): 1498. https://doi.org/10.3390/ijerph14121498

Azovtseva N.A. (2004) The effect of salt antifreezes on the ecological state of urban soils [dissertation]. Moskva. (in Russian).

Bagdasaryan A.V. (2008) The grouping of saline soils and crops according to the degree of plant sensitivity to salinity. URL: https://www.anau.am/images/stories/journal/2_2008/ Agro_2_2008/23-25_2_2008.pdf (accessed 17 may 2018). (in Russian).

Cain N.P. et al. (2001) Review of the effects of $\mathrm{NaCl}$ and other road salts on terrestrial vegetation in Canada. Environment Canada, Commercial chemicals evaluation branch.

Coldsnow K.D., Mattes B.M., Hintz W.D., Relyea R.A. (2017) Rapid evolution of tolerance to road salt in zooplankton. Environmental Pollution 222: 367-373. https://doi.org/10.1016/j. envpol.2016.12.024

Cunningham M.A., Snyder E., Yonkin D., Ross M., Elsen T. (2008) Accumulation of deicing salts in soils in an urban environment. Urban Ecosyst. 11: 17-31. https://doi.org/10.1007/s1 1252-007-0031-x soil horizons by precipitation. Simultaneously soil toxicity for higher plants and soil microorganisms is reduced.

The use of de-icing salts is necessary to keep roads safe for humans in the winter period. However, it is important to base on the principle of maximum environmental safety. When calculating permissible doses of de-icing agents, the lowest adverse effect concentrations need to be taken into account. According to our results, the doses of de-icing agents not exceeding $50 \mathrm{~g} / \mathrm{m}^{2}$ do not change soil salinity and can be considered acceptable for use on roads.

\section{Acknowledgements}

The study was supported by the state research topic of SRCES RAS No. 0241-2019-0018.

FR (Federal Register) (2006) Methods for measuring the germination of seeds and the length of the roots of seedlings of higher plants to determine the toxicity of industry-related and polluted soils. FR.1.39.2006.02264. St. Petersburg. (in Russian).

Gerasimov A.O., Chugunova M.V. (2016) The study of de-icing agents effect on high plants and soil microorganisms in the laboratory and field experiments. Inzhenernaya geologiiya (Engineering geology world). 6: 48-53. (in Russian).

Gerasimov A.O., Chugunova M.V. (2018) Evaluation of the effect of anti-icing agents of different chemical composition on the growth of herbaceous plants and soil respiration. Biosfera (Biosphere). 10(4): 273-281. http://dx.doi.org/10.24855/biosfera.v10i4.461 (in Russian). https://doi.org/10.24855/biosfera.v10i4.461

GOST 26423-85 (2011) Soils. Methods for Determining the Electrical Conductivity, $\mathrm{pH}$ and Dense Residue of the Water Extract (in Russian).

Green F.B., East A.G., Salice C.J. (2019) Will temperature increases associated with climate change potentiate toxicity of environmentally relevant concentrations of chloride on larval green frogs (Lithobates clamitans)? Science of the Total Environment 682: 282-290. https://doi.org/10.1016/j.scitotenv.2019.05.018

Ke G., Zhang J. and Tian B. (2019) Evaluation and Selection of De-lcing Salt Based on Multi-Factor. Materials (Basel). 12(6): 912. doi: 10.3390/ma12060912. https://doi.org/10.3390/ma12060912 
Jacobi W.R., Goodrich B.A., Koski R.D. (2009) Environmental Effects of Magnesium Chloride-Based Dust Suppression Products on Roadside Soils, Vegetation and Stream Water Chemistry. Agricultural Experiment Station Technical Report. TR09-04. Colorado State University. $184 \mathrm{p}$.

Kopikova L.P. (1985) The study of electrical conductivity of soils and pore solutions for the purpose of diagnosing the degree of salinity [dissertation]. Moskva. (in Russian).

Muchate N.S., Nikalje G.C., Rajurkar N.S., Suprasanna P., Nikam T.D. (2016) Plant Salt Stress: Adaptive responses, tolerance mechanism and bioengineering for salt tolerance Bot. Rev. 82: 371. https://doi.org/10.1007/s12229-016-9173-y

NCHRP (National Cooperative Highway Research Program) (2007) Guidelines for the selection of snow and ice control materials to mitigate environmental impact. Transportation research board of the national academies. NCHRP report 577 . Washington, DC. Available at: http://cdnassets.hw.net/66/66/ac492fa045acb567aba3fc7d9886/nchrp-rpt-577.pdf (accessed 15 April 2019).

NutileS.A., Solan M.E. (2019) Toxicity testing of "eco-friendly" de-icing formulations using Chironomus dilutes. Environmental Pollution 246: 408-413. https://doi.org/10.1016/j.envpol.2018.12.033

Pankova Ye.I., Vorob'yeva L.A., Gadzhiyev I.M., Gorokhova I.N. (2006) The saline soils in Russia (otv. red. L.L. Shishov, Ye.I. Pankova). Moskva: Akademkniga. 857 p. (in Russian).

Polyak Y.M., Bakina L.G., Chugunova M. V., Mayachkina N.V., Gerasimov A.O., Bure V.M. (2018) Effect of remediation strategies on biological activity of oil-contaminated soil - A field study. International Biodeterioration \& Biodegradation 126: 57-68. https://doi.org/10.1016/j.ibiod.2017.10.004

Sotneva N.I. (2005) The use of express methods for estimation the soils by the degree of salinity (for example, the north Caspian lowland soils). Byulleten' Pochvennogo instituta im. V.V. Dokuchayeva. 57: 68-80. (in Russian).

Soundararajan P., Manivannan A., Ko C.H., Park J. (2019) Evaluation of relative toxicity caused by deicing agents on photosynthesis, redox homeostasis, and the osmoregulato- ry system in creeper-type plants. Horticulture, Environment and Biotechnology, 60(2). DOI:10.1007/s13580-018-0117-9. https://doi.org/10.1007/s13580-018-0117-9

Tester M., Davenport R. (2003) Na+ tolerant and Na+ transport in higher plants. Annals of Botany 9: 503-527. https://doi. org/10.1093/aob/mcg058

Tolpeshta I.I., Sokolova T.A., Sizemskaya M.L. (2000) Ion activity and electric conductivity of water extract from virgin and meliorated soils of the Dzhanybek hospital. Pochvovedeniye. 11: 1365-1376. (in Russian).

TRB (Transportation research board) (2008) Surface transportation weather and snow removal and ice control technology. Seventh international symposium on snow removal and ice control technology, 16-19 June 2008, Indianapolis, USA. Available at: http://onlinepubs.trb.org/onlinepubs/circulars/ec126. pdf (accessed 29 November 2017).

Vasil'yev P.A. (2008) Environmental problems associated with the use of de-icing agent in urban conditions. Tezisy dokladov XV mezhd. konf. «Lomonosov-2008», apr 8-12, Moskva. M.: izdvo MGU. pp. 12-13. (in Russian).

Vorob'yeva L.A., Ladonin D.V., Lopukhina O.V., Rudakova T.A., Kiryushin A.V. (2012) Chemical analysis of soils. Questions and answers. Moskva: MGU. 186 p. (in Russian).

Vozbutskaya A.Ye. (1968) Soil Chemistry. Moskva: Vysshaya shkola. 429 p. (in Russian).

Yakubov Kh.G., Nikolayevskiy V.S. (2001) The removing of sodium and chlorides from the soil in order to improve the conditions for growth and development of woody plants. Ekologiya bol'shogo goroda. Al'manakh "Problemy soderzhaniya zelenykh nasazhdeniy v usloviyakh Moskvy". Moskva: Gruppa Stagirit. 5: 100-105. (in Russian).

Zvyagintsev D.G. (1987) Soil and microorganisms. M.: MSU publishing house. (in Russian).

Zvyagintsev D.G., Babieva I.P., Zenova G.M. (2005) Soil biology. M.: MSU publishing house. (in Russian). 